\title{
PEMBENTUKAN KARAKTER DISIPLIN SISWA MELALUI GURU KELAS DI SD NEGERI 3 REJOSARI KABUPATEN OKU TIMUR
}

\author{
${ }^{1}$ Nur Rahmat, ${ }^{2}$ Sepriadi, dan ${ }^{3}$ Rasmi Daliana \\ ${ }^{1,2,3}$ Peneliti Magister Manajemen Pendidikan, Universitas PGRI Palembang \\ e-mail: nurrahmat477@gmail.com
}

\begin{abstract}
The role of educators should be able to carry out the inspiration of learning. The existence of teachers as one component in the education system greatly affects the formation of student discipline character in SD Negeri 3 Rejosari Belitang Mulya District, OKU Timur. This research was descriptive qualitative. This research provided an overview of the character of students' discipline and provide solutions in character-based learning for students in OKU Timur. Data collection techniques used in this study were observation, interviews, and documentation. The results of this study explained that teachers as educators, teachers as teachers, teachers as mentors, teachers as trainers, and teachers as evaluators. The role of classroom teachers in SD Negeri 3 Rejosari has been good already, because each class teacher has applied the five aspects of the role of the class teacher well. Efforts of classroom teachers in the formation of student character are using habituation method, exemplary, lecture and simulation. Therefore, teachers have an important role in building the character of the nation.
\end{abstract}

Keywords: Character Building, The existence of Teachers, Discipline, SD Negeri 3 Rejosari.

\section{PENDAHULUAN}

Pada saat ini, banyak terjadi peristiwaperistiwa yang di tunjukkan oleh peserta didik di Indonesia, seperti membolos pada jam pelajaran yang sedang berlangsung, sering terlambat saat masuk kelas, tidak memperhatikan guru saat menjelaskan, tidak mengerjakan tugas rumah dan sebagainya. Perlu adanya sebuah inovasi agar pelanggaran yang dibuat oleh peserta didik dapat ditanggulangi dengan baik salah satunya melalui penerapan pengembangan pendidikan karakter disiplin kepada peserta didik. "Guru kencing berdiri, murid kencing berlari”. Peribahasa ini menggambarkan pengaruh perilaku guru terhadap perilaku peserta didiknya. Pendidikikan pada tingkat sekolah dasar, perilaku guru merupakan model bagi peserta didiknya dalam berperilaku baik diluar atau didalam kelas. Perilaku guru dimasyarakat dijadikan ukuran keterlaksanaan budaya bagi anggota masyarakatnya. Peran guru sebagai pendidik merupakan peran yang berkaitan dengan tugas-tugas memberi bantuan dan dorongan, tugas-tugas pengawasan dan pembinaan serta tugas-tugas pengawasan dan pembinaan serta tugas-tugas yang berkaitan dengan mendisiplinkan peserta didik agar menjadi patuh terhadap aturan-aturan sekolah dan norma hidup dalam keluarga dan masyarakat (Djamarah, 1994) mengemukakan peranan pendidik adalah sebagai berikut : a) korektor yaitu membedakan nilai yang baik dan nilai yang buruk dalam pelaksanaan pendidikan, b) 
inspirator yaitu memberikan ilham yang baik komponen dalam sistem pendidikan sangat bagi kemajuan belajar peserta didik, c) mempengaruhi hasil dari proses belajar informatory yaitu memberikan informasi mengajar disekolah. Yang paling utama perkembangan ilmu pengetahuan dan sebagai pendidik harus menunjukkan teknologi, d) organisator yaitu mengelola kelakuan yang layak bagi guru menurut kegiatan pembelajaran, e) motivator yaitu harapan masyarakat. dalam situasi formal mampu mendorong peserta didik agar aktif guru mendidik dan mengajar peserta didik dalam proses belajar mengajar, f) ilustrator dalam kelas seorang pendidik harus sanggup yaitu pencetus ide pendidikan dan menunjukkan kewibawaan atau otoritesnya, pembelajaran, g) fasilitator yaitu artinya ia harus mampu mengendalikan, menyediakan fasilitas untuk memudahkan mengatur dan mengontrol kelakuan anak. proses pembelajaran, h) pembimbing yaitu Dengan kewibawaan ia menegakkan disiplin bisa memberikan bimbingan kearah yang demi kelancaran dan ketertiban dalam proses positif, i) demonstrator yaitu mampu belajar mengajar.

memberikan pemahaman materi pelajaran Disiplin merupakan tindakan yang kepada peserta didik dengan baik, j) menunjukkan perilaku tertib dan patuh pada pengelolaan kelas yaitu mampu mengelola peraturan. Menurut Kamus Besar Bahasa kelas dengan dinamis, k) mediator yaitu Indonesia, disiplin berarti ketaatan ( pendidik harus mengetahui manfaat media kepatuhan ) kepada peraturan ( tata tertib). pendidikan secara benar dan tepat, 1) Kata disiplin memiliki makna diantaranya supervisor yaitu pendidik mampu membantu menghukum, melatih, dan mengembangkan memperbaiki dan menilai, m) evaluator, kontrol diri anak. Disiplin akan membantu

Menurut Joni (2010) peranan pendidik anak untuk mengembangkan kontrol dirinya, harus mampu melaksanakan inspirasi dan membantu anak mengenali perilaku yang pembelajaran yaitu pendidik yang melalui salah lalu mengoreksinya. Disiplin tidak kegiatan mengajarnya mampu mengilhami identik dengan kekerasan. Karena disiplin peserta didik, artinya pendidik yang yang benar dan proporsional adalah adalah mengembangkan sebuah gagasan besar dari jika disiplin itu diterapkan dengan penuh peserta didik untuk lebih diperdalam lagi kesadaran dan kasih sayang. Apabila disiplin selama proses pembelajaran berlangsung baik diterapkan dengan emosi, amarah, dan dalam ruang kelas maupun luar kelas. kekerasan, maka yang muncul bukan disiplin Keberadaan guru sebagai salah satu yang baik, namun disiplin yang terpaksa. Di 
depan orang tua anak mungkin tampak tertentu, antara lain; penuh rasa tanggung mematuhi peraturan, namun dibelakangnya jawab, berwibawa, dewasa dan mandiri dalam anak malah membangkang. Ini jelas sikap mengambil keputusan, berdisiplin, dan yang kontra produktif. Menurut Ahmad berdedikasi dalam melaksanakan pekerjaan (2009) disiplin dapat membentuk kejiwaan guru sebagai panggilan. Pada Pasal 33 UU anak untuk memahami peraturan sehingga dia Sistem Pendidikan Nasional Nomor 20 tahun pun mengerti kapan saat yang tepat untuk 2003, bahwa, "Pendidikan nasional berfungsi melaksanakan peraturan dan kapan pula mengembangkan dan membentuk watak serta mengesampingkannya. Sedangkan peraturan peradaban bangsa yang bermartabat dalam itu sendiri ada dalam keseharian hidup anak. rangka mencerdaskan kehidupan bangsa, Kondisi kejiwaan anak butuh diatur sehingga bertujuan untuk berkembangnya potensi seorang anak akan merasa tenteram jika peserta didik agar menjadi manusia yang hidupnya teratur. beriman dan bertakwa kepada Tuhan Yang

Penerapan karakter disiplin ini Maha Esa, berakhlak mulia, sehat, berilmu, diterapkan oleh guru di SD Negeri 3 Rejosari cakap, kreatif, mandiri, dan menjadi warga kepada peserta didiknya. Dalam pembentukan negara yang demokratis serta bertanggung karakteristik disiplin diharapkan agar jawab(Wiyani, 2013).

memiliki sikap disiplin dalam kehidupan Orang tua harus meluangkan sehari-hari sejak usia dini. Melatih anak waktunya untuk mendidik anak-anak. Ibu untuk mentaati peraturan akan sama halnya yang bekerja di luar rumah tidak disarankan dengan melatih mereka untuk bersikap mempercayakan sepenuhnya pendidikan disiplin. Sikap disiplin akan lebih efektif dan anak-anak usia dini kepada pembantu berhasil jika disosialisasikan kepada anak, dirumah. Anak usia sekolah (6-12 tahun) dilakukan terlebih dahulu oleh orang tua serta sudah mulai memasuki lingkungan diluar lingkungannya. Anak juga akan mudah rumahnya, anak akan lebih percaya dengan menerapkan peraturan tersebut bila ada perkataan gurunya dari pada orang tuanya penghargaan atau hukuman yang jelas. sendiri. Pendidikan karakter anak usia Keberadaan guru di sekolah pada hakikatnya Sekolah Dasar sangat efektif dilakukan berperan sebagai pengganti orang tua, bagi disekolah. Lingkungan sekolah (guru dan para siswanya. Ia menjadi tokoh panutan bagi siswa) memiliki peran yang kuat dalam peserta didiknya. Sebagai pendidik, seorang membentuk karakter anak (Kristiawan, 2015). guru harus memenuhi standar kualitas pribadi 
Penyelenggaraan pendidikan karakter Fenomena yang teramati ketika peneliti menjadi satu hal yang harus dilakukan di melakukan observasi awal menunjukkan jenjang pendidikan manapun, khususnya pada bahwa SD Negeri 3 Rejosari memiliki tenaga jenjang pendidikan Sekolah Dasar di SD pendidik yang baik. SD Negeri 3 Rejosari Negeri 3 Rejosari Kecamatan Belitang Mulya memiliki prestasi dalam bidang akademik di Kabupaten OKU Timur, karena pendidikan tingkat regional kemudian pernah mengikuti sebagai pondasi utama dalam melanjutkan lomba cerdas cermat sampai ke Provinsi. kejenjang pendidikan ke Sekolah Menengah Meski demikian tentu dalam beberapa hal Pertama bagi tumbuh kembang generasi masih memerlukan pembenahanmuda Indonesia. Dengan demikian, pembenahan, khususnya pada aspek pendidikan karakter menjadi isu penting pengembangan sumber dayanya dan dalam menciptakan generasi penerus bangsa. pembentukan karakter siswa. Oleh karena itu Meskipun pendidikan karakter telah perlu dilihat secara mendalam kondisi diaplikasi di Kabupaten OKU Timur pengembangan sumber daya pendidikan dan khususnya wilayah Belitang Mulya melalui pengembangan karakter yang ada di SD kurikulum pada setiap jenjang pendidikan, Negeri 3 Rejosari Kecamatan Belitang Mulya penelitian yang dilakukan di Kabupaten OKU di Kabupaten OKU Timur.

Timur ini berjudul Pembentukan Karakter

Disiplin Siswa Melalui Guru Kelas di SD LANDASAN PENDIDIKAN KARAKTER Negeri 3 Rejosari Kabupaten OKU Timur.

Guru yang berkarakter adalah guru

SD Negeri 3 Rejosari adalah salah yang memiliki nilai dan keyakinan yang satu SD Negeri yang berdiri di wilayah dilandasi hakikat dan tujuan pendidikan serta Belitang Mulya Kabupaten OKU Timur. Di digunakan sebagai kekuatan moral dalam SD Negeri 3 Rejosari cukup diminati oleh menjalankan tugasnya sebagai pendidik. masyarakat khususnya masyarakat di wilayah Untuk membuat guru dikatakan hebat, berikut Rejosari dan sekitarnya, SD Negeri 3 Rejosari ada beberapa upaya dari guru SD Negeri 3 memiliki Akreditasi A, bahkan merupakan Rejosari untuk menjadi guru berkarakter yang salah sekolah negeri favorit. Hal ini hebat yaitu sebagai berikut : a) Mencintai menunjukkan kepercayaan masyarakat anak. Cinta yang tulus kepada anak adalah terhadap sekolah tersebut dalam kategori modal awal mendidik anak. Guru menerima tinggi. Kepercayaan masyarakat di atas tentu anak didiknya apa adanya, mencintai tanpa terjadi melalui proses, dan waktu yang lama. syarat dan mendorong anak untuk melakukan 
yang terbaik pada dirinya. Penampilan yang Kewarganegaraan, pendidikan agama, dan penuh cinta adalah dengan senyum, sering mata pelajaran terkait lainnya. Pendapat tampak bahagia dan menyenangkan dan ketiga, karakter pendidikan nasional pandangan hidupnya positif, b) Bersahabat diintegrasikan ke dalam semua mata pelajaran dengan anak dan menjadi teladan bagi anak. (Kristiawan, 2015).

Guru harus bisa digugu dan ditiru oleh anak. Dalam rangka meningkatkan Oleh karena itu, setiap apa yang diucapkan di profesionalitasnya, guru harus selalu belajar hadapan anak harus benar dari sisi ilmuwan, dan belajar. Di sinilah peran guru kelas moral, agama, dan budaya, c) Mencintai dituntut untuk dapat membangun interaksi pekerjaan guru. Guru yang mencintai sebaik mungkin dengan peserta didik di SD pekerjaannya akan senantiasa bersemangat. Negeri 3 Rejosari sehingga dapat tercipta Guru yang hebat tidak akan merasa bosan dan suasana belajar yang menyenangkan dan terbebani. Guru yang hebat akan mencintai selalu memotivasi siswa untuk terus belajar. anak didiknya satu persatu, memahami Maka, yang perlu disiapkan untuk kemampuan akademisnya, kepribadiannya, melaksanakan pembelajaran yang sempurna kebiasaannya, dan kebiasaan belajarnya. d) adalah penguasaan, pemahaman dan Luwes dan mudah beradaptasi dengan pengembangan materi, penggunaan metode perubahan. Guru harus terbuka dengan teknik yang tepat, efektif dan senantiasa melakukan mengajar baru, membuang rasa sombong dan pengembangannya, serta menumbuhkan selalu mencari ilmu. e) Tidak pernah berhenti kepribadian kepada peserta didik. belajar ( Mujtahid, 2011).

Untuk mencegah krisis moral yang lebih parah, kini usaha tersebut dimulai melalui karakter pendidikan bangsa. Dalam pemberian karakter pendidikan nasional di sekolah, terlalu banyak ahli yang tidak setuju satu sama lain. Setidaknya ada tiga pendapat yang berkembang. Pertama, mengingat karakter pendidikan nasional sebagai subjek yang berdiri sendiri. Pendapat kedua, mengingat karakter pendidikan nasional yang terintegrasi dalam mata kuliah
Menurut Lickona (2013), tujuan pembentukan karakter ada tujuh, yaitu: a) merupakan cara terbaik untuk menjamin anak-anak (siswa) memiliki kepribadian yang baik dalam kehidupannya, b) merupakan cara untuk meningkatkan prestasi akademik, c) sebagian siswa tidak dapat membentuk karakter yang kuat bagi dirinya di tempat lain, d) mempersiapkan siswa untuk menghormati pihak atau orang lain dan dapat hidup dalam masyarakat yang beragam, e) berangkat dari akar masalah yang berkaitan dengan problem 
moral sosial, seperti ketidaksopanan, dibuat dibicarakan dengan anak. Mengajak ketidakjujuran, kekerasan, pelanggaran mereka bicara berarti membuka ruang ide kegiatan seksual, dan etos kerja (belajar) yang yang rasional dari anak dan mereka akan rendah, f) merupakan persiapan terbaik untuk lebih mudah menerima aturan yang dibuat menyongsong perilaku di tempat kerja, g) bersama. Dalam membuat aturan diperlukan mengajarkan nilai-nilai budaya merupakan prosedur operasi standar ( SOP ), 4) Membuat bagian dari kerja peradaban. aturan harus disertai dengan konsekuensi.

Menurut Ihsan (2015), ada tujuh cara membentuk karakter disiplin, yaitu sebagai berikut: 1) Akrab dengan anak, namun syaratnya harus punya kedekatan emosional. Apabila mendisiplinkan anak tanpa kedekatan emosinal (emotional bonding), hanya akan membuat hubungan yang kering, tanpa makna dan tanpa jiwa. 2) Orang tua tidak boleh berbohong. Agar anak mau berhenti berbuat buruk, tindakan praktis kedua orang tua adalah menjadi orang tua yang dipercaya oleh anak. Anak yang tidak patuh pada orang tua adalah anak yang sering dibohongi orang tua. Orang tua minta maaf pada anak jika berbuat salah. Permintaan maaf ini untuk menjaga konsistensi pada kebenaran. 3) Orang tua menegosiasikan batasan. Membuat aturan di keluarga harus dengan jelas. Saat kebebasan seseorang berbenturan dengan kebebasan orang lain, maka dibutuhkan peraturan atau batasan. Saat kebebasan diberikan tapi hal itu malah membahayakan diri sendiri,orang lain, seta bertentangan dengan hukum agama, negara dan norma masyarakat., maka dibutuhkan peraturan. Aturan yang dibuat
Salah satu bagian penting soal disiplin adalah ketegasan termasuk unsur di dalamnya adalah soal sistem ketegasan. Jika kewajiban tanpa ada konsekuensi maka sifatnya berubah menjadi sukarela. Konsekuensi selain berbentuk berbentuk ganjaran (reward), 5) Tegas bertindak konsisten. Konsisten adalah modal penting untuk menguasai anak. Orang tua wajib punya otoritas di hadapan anak. Tapi setelah punya otoritas tidak dibenarkan bertindak otoriter, 6) Apabila anak berbuat baik, maka itu harus diakui dan diapresiasi. Tindakan yag efektif untuk menghentikan dan mengurangi perbuatan buruk anak adalah memperbesar wilayah kebaikannya. Semakin banyak perbuatan baik anak, semakin sedikit perbuatan buruknya. Namun tidak semua reward baik untuk anak. Ada sebagian perbuatan yang tidak boleh diiming-imingi dengan reward. Atau jika anak mensyaratkan reward terlebih dahulu. Hal itu berbahaya, karena ini akan menjadi konsep diri anak di kemudian hari, yaitu melakukan kebaikan harus ada rewardnya. Reward tidak boleh diberikan pada pekerjaan atau tugas yang 
seharusnya memang wajib dilakukan anak, pelajaran yang diampu, memiliki tanggung tapi boleh diberikan jika mengerjakan diluar jawab membangun moral dan karakter peserta tugas utamanya, 7) Tanamkan nilai, didik (Zamroni, 2009). Guru kencing berdiri, pandangan hidup, moral, etika pada diri anak. murid kencing berlari”. Peribahasa ini

Proses pendidikan yang dapat dilakukan

di SD Negeri 3 Rejosari untuk mengembangkan disiplin peserta didik yaitu dengan cara sebagai berikut; 1) Mengembangkan pikiran dan pemahaman serta perasaan positif siswa tentang manfaat disiplin bagi perkembangan diri. Mengembangkan keterampilan diri (life skill) siswa agar memiliki disiplin. Mengembangkan pemahaman dan perasaan positif siswa tentang aturan dan manfaat mematuhi aturan dalam kehidupan. 3) Mengembangkan kemampuan siswa menyesuaikan diri secara sehat. Mengembangkan kemampuan siswa untuk mengembangkan kontrol internal terhadap perilaku sebagai dasar perilaku disiplin. 5) Menjadi modeling dan mengembangkan keteladanan. 6) Mengembangkan sistem dan mekanisme pengukuhan positif maupun negatif untuk penegakan disiplin di sekolah.

\section{PERAN GURU}

Mengajar tidak sekedar mentransfer ilmu pengetahuan, teknologi dan ketrampilan, melainkan mengajar juga mentransfer kehidupan. Implikasi yang paling dekat adalah semua pengajar, tidak pandang mata menggambarkan pengaruh perilaku guru terhadap perilaku muridnya. Pendidikan di tingkat prasekolah dan tingkat dasar, perilaku guru merupakan model bagi murid dalam berperilaku baik di dalam maupun di luar kelas. Ucapan dan perintah guru sangat dipatuhi oleh murid-muridnya. Bahkan sering terjadi bahwa ucapan dan perintah guru yang didengar anak di sekolah lebih dipatuhi oleh anak daripada ucapan dan perintah orang tuanya. Perilaku guru di masyarakat dijadikan ukuran keterlaksanaan budaya bagi anggota masyarakatnya..Kelestarian budaya local masyarakat menjadi tanggung jawab anggota masyarakatnya. Sedang guru menjadi barometernya. Guru yang melaksanakan tugas di luar daerah kelahirannya, dituntut untuk mengenal budaya masyarakat di mana ia melaksanakan tugasnya. Untuk dapat melaksanakan dan melestarikan budaya masyarakat barunya, guru harus mengenalnya dengan baik. Pembentukan karakter anak didik merupakan tugas bersama dari orang tua, masyarakat, dan pemerintah. Ketiga pihak tersebut secara bersama-sama atau simultan melaksanakan tugas membentuk karakter anak didik. Guru merupakan pihak dari pemerintah yang bertugas membentuk 
karakter anak didik, terutama selama proses pendidikan dasar, dan pendidikan menengah. pendidikan di sekolah. Kemudian orang tua Ada beberapa peranan yang seharusnya sekaligus sebagai anggota masyarakat dilakukan oleh seorang Guru dalam memiliki waktu yang lebih banyak dalam menjalankan tugasnya, yaitu :(1) Sebagai membina karakter anaknya. Keberhasilan informator. Sebagai pelaksana cara mengajar pembentukan karakter anak didik di sekolah, informatif, laboratorium, studi lapangan, dan apabila murid dan guru berasal dari budaya sumber informasi kegiatan akademik maupun lokal yang sama. Guru yang mengenal lebih umum, (2) Sebagai Organisator. Pendidik dalam budaya lokal anak didiknya akan lebih sebagai organisator, pengelola kegiatan lancar dan lebih berhasil dalam pembentukan akademik, silabus, workshop, jadwal karakter anak didiknya dibandingkan dengan pelajaran, dll (3) Sebagai Motifator, peran guru yang kurang mengenal atau kurang pendidik sebagai motifator ini penting memahami budaya lokal anak didiknya. artinya dalam rangka meningkatkan Merupakan tugas dan tantangan besar bagi kegairahan dan pengembanganguru yang ditugaskan di masyarakat yang pengembanagan kegiatan belajar siswa, (4) budayanya berbeda dengan budaya guru yang Sebagai Pengarah/Direktor, pendidik dalam bersangkutan. hal ini harus membimbing dan mengarahkan

Terdapat 4 komponen kompetensi kegiatan belajar siswa sesuai dengan tujuan yang harus dimiliki oleh guru yaitu yang dicita-citakan, guru harus kompetensi pedagogis, kompetensi juga'"Handayani'. (5) Sebagai Inisiator. professional, kompetensi sosial dan Pendidik dalam hal ini sebagai pencetus idekompetensi kepribadian. Guru merupakan ide dalam proses belajar, (6)Sebagai teladan bagi siswa dan memiliki peran yang Transmitter. Dalam kegiatan belajar guru juga sangat besar dalam pembentukan karakter akan bertindak selaku penyabar siswa. Jika kita menengok kembali tugas guru kebijaksanaan pendidikan dan pengetahuan yang luar biasa. Dalam UU Guru dan Dosen, Selain itu lebih terperinci lagi, guru UU no 14 tahun 2005, guru didefinisikan memiliki beberapa peranan, yaitu :(1) Guru sebagai pendidik professional dengan tugas sebagai sumber belajar.Peran guru sebagai utama mendidik, mengajar, membimbing, sumber belajar merupakan peran yang sangat mengarahkan, melatih, menilai, dan penting. Peran sebagai sumber belajar mengevaluasi peserta didik pada pendidikan berkaitan erat dengan penguasaan materi anak usia dini jalur pendidikan formal, pelajaran. Dikatakan guru yang baik 
manakala iya dapat menguasai materi

Peran guru sebagai pendidik (nurturer) pelajaran dengan baik, sehingga benar-benar merupakan peran-peran yang berkaitan ia berperan sebagai sumber belajar bagi anak dengan tugas-tugas memberi bantuan dan didiknya. (2)Guru sebagai Fasilitator. Sebagai dorongan (supporter), tugas-tugas fasilitator, guru berperan dalam pemberian pengawasan dan pembinaan (supervisor) serta pelayanan untuk memudahkan siswa dalam tugas-tugas yang berkaitan dengan kegiatan proses pembelajaran, (3)Guru mendisiplinkan anak agar anak itu menjadi sebagai pengelola. Sebagai pengelola patuh terhadap aturan-aturan sekolah dan pembelajaran (learning manager), guru norma hidup dalam keluarga dan masyarakat. berperan dalam menciptakan iklim belajar Peran guru sebagai model atau contoh bagi yang memungkinkan siswa dapat belajar anak. Setiap anak mengharapkan guru mereka secara nyaman. (4) Guru sebagai dapat menjadi contoh atau model baginya. Demonstater, yang dimaksud dengan peran Oleh karena itu tingkah laku pendidik baik guru sebagai demonstater adalah peran untuk guru, orang tua atau tokoh-tokoh masyarakat mempertunjukan kepada siswa segala sesuatu harus sesuai dengan norma-norma yang yang dapat membuat siswa lebih mengerti dianut oleh masyarakat, bangsa dan negara. dan memahami setiap pesan yang Karena nilai nilai dasar negara dan bangsa disampaikan. Ada dua konteks guru sebagai Indonesia adalah Pancasila, maka tingkah demonstater: pertama guru harus menunjukan laku pendidik harus selalu diresapi oleh nilaisikap-sikap yang terpuji, yang kedua guru nilai Pancasila.

harus dapat menunjukan bagaimana caranya agar setiap materi pelajaran bisa lebih METODE PENELITIAN dipahami dan dihayati oleh setiap siswa. Penelitian ini berupa penelitian Motivasi sangat erat hubungannya dengan kualitatif deskriptif. Menurut Sugiyono kebutuhan, sebab memang motivasi muncul (2013) metode penelitian merupakan cara karena kebutuhan. Proses pembelajaran akan ilmiah untuk mendapatkan data dengan tujuan berhasil manakala siswa mempunyai motifasi dan kegunaan tertentu. Data yang diperoleh dalam belajar. Oleh sebab itu, guru seperti hasil pengamatan, hasil wawancara, menemukan motivasi belajar siswa. Untuk hasil pemotretan, analisis dokumen, catatan memproleh hasil belajar yang optimal, guru lapangan, disusun peneliti di lokasi penelitian dituntut kreatif membangkitkan motivasi (Gunawan, 2013). Menurut Sukmadinata belajar siswa.

(2006) menjelaskan Penelitian deskriptif 
adalah suatu bentuk penelitian yang ditujukan 2009). Dalam rangka pengumpulan data yang untuk mendeskripsikan fenomena-fenomena dibutuhkan oleh penelitian ini, baik data yang ada, baik fenomena alamiah maupun primer ataupun data sekunder. diperlukan fenomena buatan manusia. Fenomena itu bisa teknik pengumpulan data yaitu : (1) Metode berupa bentuk, aktivitas, karakteristik, Wawancara yaitu pertemuan dua orang untuk perubahan, hubungan, kesamaan, dan bertukar informasi dan ide melalui tanya perbedaan antara fenomena yang satu dengan jawab, sehingga dapat dikontruksikan makna fenomena lainnya. Berdasarkan definisi di dalam suatu topik tertentu (Sugiyono, 2013). atas Penelitian ini memberikan gambaran Sumber data yang diwawancarai yaitu : a) tentang pembentukan karakter siswa melalui Guru kelas 1, 2, 3, 4, 5, dan 6 SD Negeri 3 guru kelas dan memberikan solusi dalam Rejosari untuk memperoleh data tentang pembelajaran yang berbasis karakter bagi pembentukan karakter disiplin siswa. b) siswa di daerah Belitang Mulya khususnya Peserta didik untuk memperoleh bagaimana siswa dan siswi di SD Negeri 3 Rejosari sikap dan perilaku siswa terhadap Kecamatan Belitang Mulya Kabupaten OKU pelaksanaan pendidikan karakter disiplin Timur. Data dari sekolah di SD Negeri 3 yang dilakukan di SD Negeri 3 Rejosari, c) Rejosari sebagai data primer. Teknik Kepala sekolah, untuk memperoleh data pengumpulan data yang digunakan dalam tentang profil sekolah, dan hal-hal yang penelitian ini adalah observasi, wawancara, berhubungan dengan upaya-upaya yang dan dokumentasi.

dilakukan dalam pembentukan karakter

Penelitian ini bertujuan untuk disiplin di SD Negeri 3 Rejosari.

memperoleh data-data atau peristiwa yang (2) Observasi merupakan suatu terjadi khususnya yang digunakan dalam proses yang kompleks, suatu proses yang pembentukan karakter disiplin siswa di SD tersusun dari berbagai proses biologis dan Negeri 3 Rejosari Kecamatan Belitang Mulya psikologis. Dua di antara yang terpenting Kabupaten OKU Timur. Pendekatan kualitatif adalah proses-proses pengamatan dan deskriptif diuraikan dengan kata-kata menurut ingatan. Observasi merupakan salah satu pendapat informan, apa adanya sesuai dengan teknik pengumpulan data yang digunakan pertanyaan penelitiannya, kemudian dianalisis dalam penelitian kualitatif (Emzir, 2011). pula dengan kata-kata apa yang Menurut Sutrisno (2004), sebagai metode melatarbelakangi informan berperilaku, ilmiah, observasi biasanya diartikan sebagai berpikir, berperasaan, dan bertindak (Usman, pengamatan dan pencatatan dengan sistematis 
atas fenomena-fenomena yang diteliti. melengkapi data utama. Studi dokumen Observasi yang digunakan untuk menggali merupakan pelengkap dari penggunaan data dari sumber data yang berupa peristiwa, metode observasi dan wawancara dalam tempat atau lokasi dan benda serta rekaman penelitian kualitatif. Metode ini digunakan gambar (Sutopo, 2002: 64). Sebagai metode untuk mengumpulkan data yang berkaitan ilmiah, observasi biasanya diartikan sebagai dengan tata tertib di SD Negeri 3 Rejosari dan pengamatan dan pencatatan secara sistematik data-data tentang guru dan siswa yang berasal terhadap gejala yang tampak pada objek dari dokumen- dokumen.

penelitian (Margono, 2010). Metode ini digunakan untuk meneliti dan mengobservasi secara langsung mengenai upaya guru kelas dalam pembentukan karakter disiplin peserta didik di SD Negeri 3 Rejosari.

3) Dokumentasi merupakan catatan peristiwa yang sudah berlalu. Dokumen bisa berbentuk tulisan, gambar, atau karya-karya monumental dari seorang. Dokumen yang berbentuk tulisan misalnya catatan harian, sejarah kehidupan (life histories), ceritera, biografi, peraturan, kebijakan. Dokumen yang berbentuk gambar misalnya foto, gambar hidup, sketsa dan lain-lain. Dokumen yang berbentuk karya misalnya karya seni, yang dapat berupa gambar, patung, film dan lainlain. Hadari (2005) menyatakan bahwa studi dokumen adalah "cara pengumpulan data melalui peninggalan tertulis terutama berupa arsip-arsip dan termasuk juga buku mengenai pendapat, dalil yang berhubungan dengan masalah penyelidikan". Studi dokumen sebagai data tambahan (sekunder), akan tetapi data ini berfungsi memperjelas dan

\section{HASIL PENELITIAN DAN PEMBAHASAN}

Peranan Guru Kelas dalam

Pembentukan Karakter Disiplin Peserta Didik di SD Negeri 3 Rejosari Kecamatan Belitang Mulya Kabupaten OKU Timur yaitu : 1) guru sebagai pendidik, peranan guru sebagai pendidik artinya guru merupakan teladan, panutan, dan tokoh yang akan diidentifikasikan oleh peserta didik, mendidik peserta didik untuk menjadi siswa yang teladan, sopan dan santun, guru mendidik peserta didik untuk disiplin waktu, dan memberi contoh yang baik agar peserta didik dengan sendirinya bersikap disiplin (Melalui wawancara peneliti dengan Kepala Sekolah Bapak Saimin, S.Pd. SD dan wawancara dengan guru kelas 1 yaitu Ibu Miswantini, S.Pd.SD pada bulan Oktober 2017. Temuan Ahmad dkk (2017) juga menyebutkan guru bertanggungjawab untuk menjadi model yang memiliki nilai-nilai moral dan memanfaatkan kesempatan untuk mempengaruhi siswasiswanya. 2) guru sebagai pengajar, peranan 
guru sebagai pengajar artinya guru selalu dan baik, mengevaluasi pembelajaran dengan mengajar dengan membuat rencana melakukan penilaian pada saat proses pelaksanaan pembelajaran, dan mendesain pembelajaran berlangsung dan menilai hasil pembelajaran, guru mengajar dengan RPP pembelajaran, guru mengukur sejauh mana digunakan sebagai panduan, guru juga peserta didiknya memahami pelajaran yang mengajarkan bagaimana menjadi peserta sudah diberikan dengan mengevaluasi proses didik yang disiplin (Melalui Wawancara dan hasil pembelajarannya, dengan guru peneliti dengan guru kelas 6 yaitu Ibu Siti mengevaluasi akan mengetahui mana siswa Kholilatin, S.Pd.SD pada bulan Oktober yang sudah bisa dan yang belum bisa 2017). 3) guru sebagai pembimbing, artinya (Melalui wawancara dengan guru kelas 2 Ibu peranan guru membimbing peserta didik Muasih, S.Pd. SD pada bulan Oktober 2017). untuk mematuhi tata tertib sekolah terutama Selain itu, adapun tujuan guru kelas saat di dalam kelas seperti memperhatikan dalam pembentukan Karakter Disiplin yaitu guru saat menjelaskan pelajaran yang sedang untuk kepentingan pertumbuhan individu berlangsung di SD Negeri 3 Rejosari ( secara integral, pendidikan karakter disiplin Melalui wawancara peneliti dengan Bapak memiliki tujuan jangka panjang yang Maniso Sujari, S.Pd, SD pada bulan Oktober mendasarkan diri pada tanggapan aktif 2017). kontekstual individu atas impuls natural

Melalui wawancara dengan guru kelas sosial yang diterimanya yang pada gilirannya 3 Ibu Sri Nurhayati, S.Pd.SD pada bulan semakin mempertajam visi hidup yang akan Oktober 2017). 4) guru sebagai pelatih, diraih lewat proses pembentukan terusartinya guru melatih peserta didik untuk menerus. Dijelaskan bahwa "agar peserta selalu mengerjakan tugasnya, guru melatih didik menjadi anak yang berhasil dan peserta didik jika diberi tugas rumah untuk membiasakan disiplin sejak usia dini. Agar dikerjakan mandiri, guru melatih peserta peserta didik menjadi anak yang disiplin baik didik untuk senantiasa membiasakan diri di sekolah maupun di rumah, bersikap disiplin baik di sekolah maupun di mengimplementasikan atau mengaplikasikan rumah, dan guru melatih peserta didik untuk hidup yang baik dan teratur, peserta didik mengerjakan soal latihan. Dan wawancara menjadi siswa yang berhasil, karena dengan guru kelas 4 ibu Kristianti, S.Pd, SD membentuk Karakter Disiplin merupakan pada bulan Oktober 2017 5) guru sebagai dasar seluruh dari kesuksesan. evaluator, memberikan penilaian dengan jujur 
Hasil dari pelaksanaan pendidikan dan dapat dianalisis bahwa upaya guru kelas penanaman karakter disiplin bagi peserta dalam pembentukan karakter disiplin siswa di didik, bisa dilihat dari perubahan sikap dan SD Negeri 3 Rejosari Kabupaten OKU Timur perilaku yang dialami siswa selama masa yaitu dengan menggunakan beberapa metode, pendidikan di SD Negeri 3 Rejosari . antara lain pembiasaan, keteladanan, Memang susah untuk mengidentifikasi ceramah, diskusi, dan simulasi. perubahan sikap dan perilaku tersebut Mengupayakan suatu pembiasaan dengan sehingga dapat dikatakan sebagai karakter metode bercerita dalam pembelajaran guru disiplin mulia. Disiplin terhadap peraturan menyelipkan cerita seputar pentingnya sekolah, hasil dari nilai karakter disiplin juga pembentukan karakter disiplin. Karena terlihat dari program harian yang peserta didik tingkat dasar lebih sering dilaksanakan, sehingga peserta didik terlatih melihat atau mengamati tingkah laku orang untuk bertindak disiplin. Hal tersebut lain. Di dalam mengupayakan pembentukan dibuktikan dengan disiplin ketika datang ke karakter disiplin peserta didik dibiasakan Sekolah, disiplin dalam mengerjakan tugas- untuk menaati peraturan-peraturan sekolah tugas, dan terlihat dari antusias siswa maka terwujudlah karakter disiplin tersebut terhadap program-program dalam membina pada diri peserta didik.

karakter disiplin peserta didik, seperti

Dari berbagai proses yang dilakukan pembiasaan 5S (senyum, salam, sapa, sopan, dalam memberikan pendidikan dan dan santun). Dalam pelaksanaannya, penanaman nilai karakter disiplin bagi peserta keteladanan dilaksanakan dalam proses didik, pastinya ada tujuan yang ingin dicapai kegiatan itu sendiri, misalnya perbuatan yang sebagai hasil dari pelaksanaan tersebut. dilakukan oleh pendidik akan mudah diikuti Namun tidak semua program yang telah oleh peserta didik. Metode keteladanan dijalankan berjalan sesuai apa yang dilaksanakan sebagai wujud pemberian diharapkan. Tetapi paling tidak, ada karakter contoh baik yang dilakukan pendidik disiplin minimal yang telah peserta didik terhadap peserta didik. Metode ini berkaitan tunjukkan dalam sikap dan perilaku seharidengan kegiatan sehari-hari di lingkungan hari sebagai wujud dari terinternalisasinya sekolah, seperti halnya keteladanan dalam nilai-nilai karakter disiplin pada diri peserta berperilaku, bertutur. didik di SD Negeri 3 Rejosari, hal itu

Setelah pengambilan data melalui dibuktikan dengan hasil observasi dan observasi, wawancara, dan dokumentasi maka wawancara peneliti kepada peserta didik yang 
menurut peneliti sudah mencerminkan nampak pada diri peserta didik suatu kegiatan yang berkarakter disiplin. Nilai perubahan sikap dan perilaku yang karakter disiplin yang tercermin pada peserta mencerminkan karakter disiplin. didik, seperti datang ke Sekolah tepat waktu, kemudian sebelum masuk kelas peserta didik

\section{DAFTAR PUSTAKA}

melaksanakan kegiatan apel pagi dengan membaca do'a dan bersalaman kepada guru dan kemudian masuk ke dalam kelas masingmasing.

\section{KESIMPULAN}

Peranan Guru Kelas Dalam Pembentukan Karakter Disiplin Siswa di SD Negeri 3 Rejosari Kecamatan Belitang Mulya Kabupaten OKU Timur adalah guru sebagai pendidik, guru sebagai pengajar, guru sebagai pembimbing, guru sebagai pelatih, dan guru sebagai evaluator. Peran guru kelas di SD Negeri 3 Rejosari sudah baik sekali, karena masing-masing guru kelas sudah menerapkan kelima aspek peranan guru kelas tersebut dengan baik. Upaya Guru Kelas Dalam Pembentukan Karakter Siswa yaitu dengan menggunakan metode pembiasaan, keteladanan, ceramah dan simulasi. Dari metode-metode tersebut, lulusan dari SD Negeri 3 Rejosari yang harus dimiliki setiap peserta didiknya, yaitu: disiplin yang berasal dari dalam individu itu sendiri dan disiplin yang datangnya dari luar dirinya. Dari berbagai metode dan program yang dicanangkan di SD Negeri 3 Rejosari, telah
A, Doni Koesoema. (2009). Pendidikan Karakter (Utuh dan Menyeluruh). Yogyakarta: PT Kanisius.

Ahmad, S., Kristiawan, M., Tobari, T., \& Suhono, S. (2017). Desain Pembelajaran SMA Plus Negeri 2 Banyuasin III Berbasis Karakter Di Era Masyarakat Ekonomi ASEAN. Iqra (Educational Journal), 2(2), 403-432.

Arikunto, Suharsimi. (2013). Prosedur Penelitian (Suatu Pendekatan Praktik). Jakarta: Rineka Cipta.

Djamarah, Syaiful Bahri. (2010). Guru dan Anak Didik Dalam Interaksi Edukatif. Jakarta: Rineka Cipta.

Emzir. (2011). Analisis Data: Metodologi Penelitian Kualitatif. PT Rajawali Press. Jakarta.

Gunawan. (2013). Metode Penelitian Kualitatif Teori dan Praktik. Jakarta: Bumi Aksara.

Hadari, Nawawi. (2005). Metode Penelitian Bidang Sosial. Gadjah Mada University Press. Yogyakarta.

Ihsan. (2015). Mengajarkan Kemandirian Kepada Anak. Depok: Khazanah Intelektual.

Joni. (2010). Pengukuran dan Penilaian Pendidikan. Surabaya: Karya Anda.

Kristiawan, M. (2015). A Model of Educational Character in High School Al-Istiqamah Simpang Empat, West 
Pasaman, West Sumatera. Research Journal of Education, 1(2), 15-20.

Kristiawan, M. (2016). Telaah Revolusi Mental dan Pendidikan Karakter dalam Pembentukkan Sumber Daya Manusia Indonesia yang Pandai dan Berakhlak Mulia. Ta'dib, 18(1), 13-25

Lickona, Thomas. (2013). Pendidikan Karakter Panduan Lengkap Mendidik Siswa Menjadi Pintar dan Baik. Bandung: Nusa Media.

Margono. (2010). Metodologi Penelitian Pendidikan. Jakarta: PT. Rineka Cipta.

Mujtahid. (2011). Pengembangan Profesi Guru. Malang: UIN-Maliki Press.

Sugiyono. (2013). Metode Penelitian Pendidikan (Pendekatan Kuantitatif, Kualitatif dan $R \& D)$. Bandung: Alfabeta.

Sukmadinata, Nana. (2006). Landasan Psikologi Proses Pendidikan. PT Remaja Rosdakarya. Bandung.

Sutrisno, Hadi. (2004). Metodologi Reseach Jilid 2. Andi Publisher. Yogyakarta.

Sutopo. (2002). Metodologi Penelitian Kualitatif. Surakarta: UNS Press.

Usman, dan Purnomo. (2009). Metodologi Penelitian Sosial. Jakarta: Bumi Aksara.

Wiyani. (2013). Membumikan Pendidikan Karakter di SD. Jogjakarta: Ar-Ruzz Media.

Zamroni. (2009). Kebijakan peningkatan mutu sekolah di Indonesia. Disajikan dalam Seminar Nasional dalam Rangka Dies Natalis Ke-45 Universitas Negeri Yogyakarta 25 April 2009. 
JMKSP

Jurnal Manajemen, Kepemimpinan, dan Supervisi Pendidikan 